\title{
PENINGKATAN MUTU PEMBELAJARAN AGAMA HINDU DALAM MEWUJUDKAN PERUBAHAN MENTAL SISWA
}

\author{
Oleh \\ Dewa A. R. Wulandari \\ SMA Dharma Praja Badung \\ d.wulandari@yahoo.co.id \\ I Nengah Juliawan \\ Institut Hindu Dharma Negeri Denpasar \\ juliawan@gmail.com
}

Diterima 21 November 2017, direvisi 12 Januari 2018, diterbitkan 28 Pebruari 2018

\begin{abstract}
Advancement of science and technology is growing rapidly can lead to positive effects and negative effects on mental students, such as the still many students who are less disciplined in dressing at school or even when following the lesson in the classroom and the lower the morale owned of the students themselves. Seeing such a phenomenon is feared will be increasingly declining mental and student behavior. So in this case the improvement of the quality of Hindu religious learning is very important role for Hindus in particular and not limited to students, because religion is a guide in behaving well in accordance with religious norms that will bring good mental changes in improving attitudes and behavior behavior, personality and budhi pekerti and moral existing in learners.
\end{abstract}

\section{Keywords: Learning of Hinduism, Mental Student.}

\section{PENDAHULUAN}

Indonesia merupakan salah satu negara yang sedang mulai berkembang. Sebagai salah satu Negara yang sedang berkembang tentu saja banyak hal yang harus menjadi perhatian pemerintah demi membangun suatu Negara yang memilki sumber daya manusia yang berpotensi. Salah satu hal yang harus diperhatikan oleh pemerintah adalah dalam bidang pendidikan. Setiap orang berhak mendapat pendidikan yang layak, seperti yang dicantumkan dalam batang tubuh UUD 1945 sesuai dengan pasal 31 ayat 1 dan 2 mengenai pendidikan yang berbunyi sebagai berikut : (Ayat1) tiap-tiap warga Negara berhak mendapat pengajaran, (Ayat 2) pemerintah mengusahakan dan menyelenggarakan suatu system pengajaran nasional. Karena pendidikan merupakan salah satu upaya untuk menjadikan seseorang menjadi 
orang yang berguna baik bagi orang lain atau pun Negara. Jika dilihat pada era globalisasi saat ini, kemajuan ilmu pengetahuan dan teknologi sangat berkembang dengan pesat, sehingga menimbulkan pengaruh positif maupun pengaruh negatif terhadap perkembangan setiap individu. Semakin berkembangnya ilmu pengetahuan maka semakin besar rasa keingintahuan seseorang untuk mencari sesuatu hal yang baru. Hal tersebutlah yang terkadang menjadikan seseorang tidak peduli akan lingkungan sekitarnya.

Salah satu fenomena yang terjadi pada masyarakat dewasa ini adalah terjadinya proses perubahan yang sangat cepat yang berkaitan dengan ilmu pengetahuan dan teknologi. Karena suatu perubahan yang sangat pesat pada masyarakat, akibatnya manusia akan berhadapan dengan suatu penyakit baru yang ditandai oleh suatu krisis (Sudibya, 1994 : 70). Penyakit baru yang dimaksud adalah merosotnya nilai-nilai keagamaan. Dimana sejak dulu bangsa kita telah mengalami suatu krisis multi dimensi yang berkepanjangan dan ini merupakan salah satu cermin bahwa bangsa Indonesia mengalami krisis moralitas. Krisis moralitas yang dimaksud adalah ketika seseorang tidak merasa puas dengan apa yang dimilikinya. Salah satu penyebab terjadinya krisis moralitas adalah rendahnya subsidi biaya pendidikan formal oleh pemerintah dewasa ini. Disamping itu juga perhatian yang kurang diberikan oleh orang tua terkadang menjadi penyebab perubahan sikap dan mental anak. "Ketidaksiapan mental menghadapi globalisasi menyebabkan kebingungan perilaku yang memunculkan penyakit-penyakit di masyarakat berupa kriminalitas seperti: korupsi, manipulasi, perampokan, penodongan, pelacuran, kenakalan remaja dan lain-lain" (Suja, 2002 : 18).

Setiap manusia yang dilahirkan di dunia ini baik dari lingkungan individual maupun lingkungan sosial, menginginkan kesempurnaan sesuai dengan watak dan bakatnya. Dalam ajaran agama Hindu kedua kebutuhan tersebut merupakan tujuan dari agama Hindu yaitu “ Moksartham Jagatdhita Ya Ca Iti Dharma " Manusia tidak hanya merupakan objek ciptaan Tuhan, akan tetapi juga merupakan subyek yaitu pelaku aktif yang dituntut untuk mewujudkan nilai-nilai keagamaan dalam kehidupan nyata. Karena keyakinan terhadap agama merupakan bagian utama dari kehidupan manusia Indonesia, oleh karena itu hendaknya harus mengarahkan kehidupan pada suatu keadaan yang di kehendaki oleh Tuhan yang berdasarkan ajaran-ajaran Kitab Suci. Tuntutan keagamaan seperti itu akan diperoleh apabila kehidupan beragama telah ditanamkan sejak masa kanak-kanak.

Penghayatan pengamalan pembelajaran agama cukup sulit ditanamkan bagi para siswa, hal ini di karenakan masih banyaknya para siswa sering melanggar peraturan yang telah ditetapkan oleh sekolah, misalnya saja dengan menggunakan pakaian yang tidak sesuai dengan ketentuan yang telah ditetapkan sekolah serta kurangnya rasa disiplin yang dimiliki para siswa saat mengikuti proses pembelajaran. Dalam hal ini tentu saja kita harus menyadari betapa pentingnya pendidikan agama itu diterapkan pada diri setiap orang khususnya bagi para siswa, karena hal tersebut dapat memberikan pengaruh positif terhadap pertumbuhan dan perkembangan mental dan tingkah laku siswa khususnya bagi para siswa.

Pembinaan ketahanan dan kesehatan mental para siswa, haruslah dilakukan secara terpadu. Penanaman nilai-nilai moral pada diri anak sejak duduk di bangku sekolah dasar dan pembinaan dini dalam keluarga merupakan salah satu usaha yang digunakan untuk meminimalisasi dan menghindari berbagai tindakan penyimpangan dan kekerasan yang sering terjadi yang terkadang terlampiaskan dalam emosi tanpa dilandasi oleh akal sehat yang kini makin merajalela. Sebab itulah, pendidikan moral bagi siswa harus diterapkan 
di semua sisi kehidupan bukan hanya dalam keluarga melainkan di sekolah atau pun di masyarakat. Sekolah sebagai salah satu lembaga pendidikan yang menjadi wadah untuk mempersiapkan, membina dan meningkatkan sumber daya manusia yang berkualitas memiliki andil yang cukup besar dalam upaya untuk membina dan menumbuh kembangkan mental dan tingkah laku siswa.

Pada dasarnya pendidikan di sekolah merupakan bagian dari pendidikan dalam keluarga yang sekaligus juga merupakan lanjutan dari pendidikan dalam keluarga. Disamping itu kehidupan di sekolah merupakan jembatan bagi para siswa yang menghubungkan kehidupan dalam keluarga dengan kehidupan dalam masyarakat kelak. Kegiatan pendidikan yang dilakukan di sekolah merupakan sebagai salah satu usaha untuk membantu mengantarkan siswa mencapai kedewasaan. Selain pendidikan atau pelajaran umum yang didapatkan oleh siswa dalam mencapai tingkat kedewasaannya, pendidikan Agama juga memegang peranan yang sangat penting karena agama merupakan dasar dari moral masyarakat, sumber nilai dan norma yang mengilhami serta mengikat masyarakat (PHDI Pusat, 1993 : 15).

Pendidikan agama sangat menentukan seseorang untuk menjadi manusia berbudi pekerti luhur. Oleh karena itu, pendidikan agama menekankan pada perubahan (transformasi) perilaku dari tidak baik menjadi baik. Pendidikan berbasis ajaran agama akan mengubah sikap dan perilaku seseorang untuk menjadi manusia berahlak mulia (Titib, 2003 : 37). Agama sebagai dasar pribadi dan sebagai way of life (cara hidup) berperan dalam pembentukkan pribadi anak harus mulai diajarkan dan berusaha diamalkan sejak dini.

Pada saat seperti sekarang ini Pendidikan Agama Hindu mempunyai peran yang sangat berarti di dalam perubahan mental dan kepribadian manusia. Agama menjadi pedoman, penuntun dan pendorong dalam diri manusia untuk mencapai kualitas hidup yang lebih baik dan sempurna. Agama memberikan motivasi hidup dan merupakan salah satu alat pengembangan dan pengendalian diri yang amat penting, oleh karena itu agama perlu dipelajari, dipahami, diyakini, dan di amalkan oleh pemeluknya agar dapat dijadikan dasar kepribadian sehingga menjadi manusia yang seutuhnya. Adapun pembelajarannya memegang peranan yang sangat penting dalam proses penerimaan informasi dari guru terhadap siswa, dimana jika sampai dalam proses penyampaian bahan ajar dari guru kepada siswa terdapat masalah maka ilmu tidak akan dapat tersampaikan dengan seutuhnya dan akan menyebabkan dalam memahaminya sehingga memungkinkan terjadinya dampak yang negatif pada siswa. Program pembelajaran agama Hindu bagi para siswa akan dapat terlaksana dengan baik sesuai dengan harapan apabila pada saat proses pembelajaran para siswa dapat mengikuti dengan tertib,dimana dalam hal ini emosi yang ada dalam diri siswa belum bisa terkendali. Kenakalan remaja dan segala penyimpangan yang dilakukan oleh siswa, ini bukan sematamata karena sikap dan gaya tingkah laku usia muda yang cenderung kearah mencoba-coba, melainkan rendahnya moralitas dan ketahanan mental siswa tersebut yang di karenakan dari berbagai faktor. Salah satu penyebab utamanya adalah faktor perhatian keluarga, faktor pendidikan di sekolah dan faktor pergaulan, dimana ketiga faktor ini sangat berpengaruh besar terhadap mental, tingkah laku dan moral siswa.

\section{PEMBAHASAN}

\subsection{Peningkatan Mutu Pembelajaran Agama Hindu Terhadap Perubahan Mental Siswa}

Melihat perkembangan siswa seperti sekarang ini, tidaklah lepas juga dari latar belakang siswa itu sendiri mulai dari segi karakter, kebiasaan-kebiasaan di rumah yang 
sering kali dibawa ke sekolah. Dengan adanya standar pembelajaran/ kurikulum dapat disesuaikan dalam mendidik siswa. Dalam hal ini orang tua merupakan pendidik yang utama dan pertama dalam membentuk kepribadian anak. Penampilan orang tua merupakan unsur-unsur pendidikan secara tidak langsung yang dengan sendirinya akan diteladani oleh anak itu sendiri. Maka sebaiknya orang tua memperlakukan anaknya dengan penuh kasih sayang dan penuh perhatian sehingga akan memudahkan untuk mendidik mental anak. Di sekolah guru membimbing dan mendidik siswa agar lebih terarah dan berprilaku yang baik diperlukan adanya pembiasaan dan latihan menjalankan ajaran agama Hindu dalam kehidupan seharihari, maka dengan mudah akan membentuk sikap yang baik pada diri siswa.

Siswa sebagai generasi muda yang merupakan sumber tenaga manusia yang dipersiapkan secara fisik, mental dan spiritual. Dengan adanya persiapan yang mantap maka akan membentuk generasi muda yang cakap dan terampil, berkepribadian kuat dan berbudi pekerti yang luhur. Dalam hal ini siswa sebagai generasi muda penerus bangsa hendaknya menjadi panutan baik dalam sikap dan tingkah lakunya, karena menjadi siswa yang teladan bukan hanya pandai dalam ilmu dan teknologi melainkan mampu menghindarkan diri dari perbuatan-perbuatan di luar norma-norma agama Hindu. Untuk menjadikan siswa yang berkepribadian kuat dan berbudi pekerti luhur, semua hal tersebut dapat diusahakan yaitu melalui pendidikan. Karena melalui pendidikan itu mampu mengubah pola fikir seseorang dalam melakukan segala hal sehingga nantinya mereka bisa berhati-hati dalam bertindak dan mengerjakan sesuatu. Semua hal tersebut dapat diusahakan melalui pendidikan, baik itu pendidikan formal maupun pendidikan non formal. Adapun peningkatan mutu pembelajaran agama Hindu terhadap perubahan mental siswa dapat dilaksanakan melalui : (1) media dalam pembinaan mental dan tingkah laku siswa, dan (2) media dalam menumbuhkan sikap keimanan siswa.

\section{a. Media Dalam Pembinaan Mental dan Tingkah Laku Siswa}

Pendidikan formal yaitu pendidikan yang di dapat di lingkungan sekolah yang diberikan oleh guru, yang dalam hal ini guru sebagai seorang pendidik dan membina siswa agar menjadi siswa yang mempunyai kepribadian yang kuat, bermoral, dan bertingkah laku sesuai dengan ajaran agama. Dalam hal ini guru mengajarkan teori tentang nilai-nilai yang harus diterapkan siswa untuk memiliki kepribadian yang beriman kepada Tuhan Yang Maha Esa. Selain itu juga guru berperan dalam memberi contoh dan teladan dalam menerapkan nilai-nilai yang telah diajarkan. Pendidikan non formal dapat dilaksanakan di lingkungan keluarga maupun di lingkungan masyarakat. Dalam pendidikan non formal ini, peranan orang tua dan tokoh agama sangat berpengaruh dalam membentuk sikap, mental dan kepribadian siswa.

Sikap anak terhadap orang tua maupun kepada guru agama, itu sangat di pengaruhi oleh sikap yang ditunjukkan orang tua maupun guru agama itu sendiri. Untuk itulah dalam membina sikap mental siswa agar mempunyai sifat yang terpuji tidaklah mungkin dengan pengertian saja, melainkan siswa itu sendiri harus membiasakan diri untuk melakukan hal-hal yang baik dalam kehidupan sehari-hari, misalnya saja dengan mengajarkan cara-cara membuat sarana persembahyangan dan upakara seperti : membuat canang, gebogan, damar kurung dan sarana upakara lainnya.

Pembelajaran agama Hindu sesungguhnya sangat diperlukan dalam membina mental siswa, karena tujuan dari agama Hindu tidak hanya menciptakan ahli-ahli yang pandai 
menguasai ilmu dan teknologi saja akan tetapi bertujuan untuk meningkatkan ketakwaan terhadap Tuhan Yang Maha Esa, mempertinggi budi pekerti, memperkuat kepribadian, dan mempertebal iman. Sebab hanya dengan pendidikan inilah manusia itu akan mampu merubah dirinya menjadi makhluk yang lebih tinggi, sehingga dapat mengolah nilai-nilai ajaran agama yang diperoleh serta berusaha meningkatkan kemampuan intelektualnya.

Pembelajaran agama Hindu bukan hanya saja mengajarkan keyakinan dan ketakwaan kepada Tuhan selain itu juga agama Hindu mengajarkan bagaimana tata cara bertingkah laku yang baik. Pembelajaran agama Hindu yang diajarkan kepada siswa dititikberatkan pada tingkah laku siswa itu sendiri, sehingga siswa akan terdidik untuk berbuat baik dan mampu membedakan mana perbuatan yang baik dan mana perbuatan yang tidak baik yang dilarang oleh ajaran agama. Untuk meningkatkan kwalitas pembelajaran agama Hindu yang kita harapkan maka ada beberapa hal yang perlu dipahami seperti tujuan pemberian materi pembelajaran agama, adapun yang menjadi tujuan dari pemberian materi pembelajaran agama Hindu terhadap perubahan mental siswa yang diharapkan adalah sebagai berikut : (1) Dengan memberikan pembelajaran agama Hindu, siswa memiliki pengetahuan dan keyakinan terhadap agama yang di anut, (2) Agar siswa dapat menghayati arti dari hakekat kehidupan yang penuh dengan tantangan dan penderitaan, (3) Agar siswa dapat meningkatkan kesadaran beragama dalam kehidupan bermasyarakat, berbangsa dan bernegara dengan menghayati dan mengamalkan ajaran agama.

Dengan memberikan pembelajaran agama Hindu sejak dini dalam hal ini memberikan latihan-latihan, pembinaan serta diberikan penjelasan dan pengertian pada siswa baik itu hal yang menyangkut hubungan manusia dengan Tuhan, manusia dengan sesamanya atau pun hubungan manusia dengan alam. Hal ini dimaksudkan agar siswa nantinya diharapkan mampu memahami ajaran agama Hindu dengan baik dan sempurna. Pembelajaran agama Hindu yang telah diberikan itu akan berhasil apabila seluruh guru, staf dan pegawai bersama-sama mengarahkan, membina, serta membimbing siswa melalui pembinaan agama yang pada gilirannya akan dapat bermanfaat bagi siswa.

\section{b. Media Dalam Menumbuhkan Sikap Keimanan Siswa}

Perubahan mental siswa haruslah mengarah pada pengembangan sikap sebagai insan berkeTuhanan Yang Maha Esa, bertakwa dan beriman serta mampu mengamalkan ajaran-ajaran agama Hindu. Dalam perubahan mental siswa sangat diperlukan peranan pembelajaran agama Hindu, karena dalam agama Hindu berisikan tentang nasehat-nasehat, norma-norma kesusilaan dan nilai-nilai pengorbanan yang perlu dilaksanakan dalam kehidupan bermasyarakat. Dengan demikian agama Hindu yang di berikan di sekolah bukanlah sekedar merupakan lapangan untuk mempertajam intelektual saja, melainkan peranan sekolah jauh lebih luas. Di sekolah siswa diajarkan bagaimana belajar bekerjasama dengan kelompok dan belajar mengendalikan diri demi kepentingan diri maupun orang lain. Jadi dalam hal ini sekolah sebagai lembaga pendidikan formal juga memiliki peran serta dalam mengembangkan sikap mental maupun sikap sosial pada diri siswa.

Fungsi guru agama Hindu di dalam perubahan mental siswa juga memiliki peran yang sangat penting di dalam menumbuhkan sikap dan tingkah lakunya, adapun fungsi guru agama Hindu adalah sebagai berikut : (1) "Pengembangan", yaitu meningkatkan keimanan dan ketakwaan siswa kepada Sang 
Hyang Widhi yang telah ditanamkan dalam lingkungan keluarga. Pada dasarnya kewajiban untuk menanamkan keimanan dan ketakwaan pada diri siswa tersebut merupakan kewajiban orang tua dalam keluarga. Dalam hal ini sekolah berfungsi untuk menumbuh kembangkan lebih lanjut keimanan dan ketakwaan pada diri siswa melalui bimbingan pengajaran dan pelatihan secara optimal yang nantinya disesuaikan dengan tingkat perkembangan siswa, (2) "Penyaluran", yaitu disini guru berfungsi untuk menyalurkan siswa yang memiliki bakat khusus di bidang agama, agar bakat yang siswa tersebut miliki mampu berkembang secara optimal sehingga dapat dimanfaatkan untuk dirinya sendiri dan dapat juga bermanfaat bagi orang lain, (3) "Perbaikan", yaitu disini guru berfungsi untuk memperbaiki kesalahan dan kekurangan maupun kelemahan siswa dalam pemahaman keyakinan dan pengamalan ajaran agama Hindu dalam kehidupan sehari-hari, (4) "Pencegahan", yaitu untuk menangkal hal-hal yang negatif yang timbul dari lingkungan sekitar mereka atau dari budaya-budaya asing yang dapat membahayakan diri dan merusak mental siswa, (5) "Sumber nilai", yaitu guru berfungsi untuk memberikan pedoman untuk mencapai kebahagiaan di dunia dan akhirat, lahir dan bathin.

Dengan demikian dalam hal ini yang dimaksud dengan peranan guru dalam pemberian materi pembelajaran agama Hindu yaitu agar terciptanya serangkaian tingkah laku yang saling berkaitan yang dilakukan dalam suatu situasi tertentu serta hubungannya dengan kemajuan perubahan mental dan tingkah laku siswa (Usman, 1990 : 4).

Dalam hal ini yang menjadi dasar dari pembelajaran agama Hindu itu sendiri adalah berpangkal pada Kerangka Dasar Agama Hindu, yang terdiri dari : Tattwa/Filsafat, Etika/Susila, Ritual/Upacara, yang mana semua ajaran tersebut bersumber pada kitab suci agama Hindu yaitu Weda. Walaupun ajaran tersebut terbagi-bagi tapi pada kenyataanya mereka tersebut terjalin menjadi satu yang harus dimiliki dan dilaksanakan oleh umat beragama Hindu. Pembelajaran agama Hindu telah termasuk di dalam tujuan pengajaran adalah untuk meningkatkan sradha bhakti siswa dalam kehidupan sehari-hari serta berpegang teguh pada ajaran-ajaran agama Hindu. Untuk mengimplementasikan ajaran agama Hindu, siswa diharapkan ikut bagian dalam kegiatan persembahyangan bersama yang dilaksanakan setiap purnama dan tilem, dalam hal ini siswa diharapkan membawa perlengkapan persembahyangan sendiri, tujuannya adalah untuk mendidik siswa agar dapat menerapkan sradha bhakti melalui persembahyangan bersama. Sehingga dengan cara demikian kita secara tidak langsung telah meningkatkan kwalitas kepercayaan terhadap Tuhan Yang Maha Esa melalui ajaran agama Hindu di sekolah yang nantinya dapat diterapkan di masyarakat.

Memberikan materi budi pekerti dalam pembelajaran agama Hindu, hal tersebut dapat membantu merubah mental siswa agar lebih terarah. Sebab Pendidikan Budhi Pekerti bertujuan untuk mengembangkan kompetensi siswa-siswi untuk menikmati hidup (life skill) yang bertumpu pada nilai kedamaian, cinta, jujur, adil, hormat, kerjasama, sederhana dan bahagia. Pembelajaran agama Hindu merupakan suatu pendidikan yang berdasarkan atas ajaran-ajaran agama Hindu. Dimana pendidikan/pembelajaran agama Hindu itu harus membina sikap mental dan tingkah laku umatnya berdasarkan atas ajaran agama Hindu yang bertujuan untuk meningkatkan Sradha dan Bhakti kepada Tuhan, mempertinggi budhi pekerti, dan memperkuat kepribadian. Siswa di didik sedini mungkin agar tidak terjerumus ke jalan yang salah. 
Untuk mewujudkan cita-cita kita sebagai agama Hindu tiada lain kebahagiaan lahiriah maupun batiniah, maka setiap umat diajarkan untuk mencapai empat tujuan hidup yang disebut dengan Catur Purusa Artha, yaitu : Dharma, Artha, Kama, dan Moksa. Dan keempat tujuan hidup tersebut hanya dapat dicapai melalui tahapan-tahapan hidup sesuai dengan jenjang pertumbuhan manusia itu sendiri. Tahapan-tahapan itu disebut dengan Catur Asrama, karena perubahan mental pada hakekatnya bertujuan untuk mewujudkan nyatakan tujuan hidup manusia pula.

Catur Asrama berasal dari kata Catur yang artinya empat, dan Asrama yang artinya tingkatan-tingkatan/tahapan-tahapan kehidupan ini. Untuk lebih jelasnya maka akan diuraikan pembagian dari catur asrama yang sebagai konsepsi dasar empat tujuan hidup yaitu : (1) Brahmacari, yaitu suatu masa kehidupan berguru untuk mendapatkan ilmu pengetahuan Weda. Pada tahapan kehidupan ini yang diprioritaskan adalah : Dharma, Artha, dan Kama, (2) Grhastha, yaitu masa hidup berumah tangga. Pada tahapan tingkatan kehidupan ini yang diprioritaskan adalah untuk mendapatkan artha yang bertujuan untuk memenuhi Kama (hawa nafsu). Jadi dalam hal ini sudah jelas bahwa suatu rumah tangga belum dapat didirikan jika belum siap dengan sumber artha. Demikian juga dengan kama yang menyangkut dorongan-dorongan hawa nafsu seperti : rasa lapar, haus dan nafsu sexs, Kama merupakan salah satu media untuk mendapatkan kebahagiaan namun perlu digaris bawahi bahwa jangan sampai kama itu memperalat manusia, (3) Wanaprastha, yaitu mengasingkan diri dari unsur-unsur keduniawian, dalam artian menjauhi diri dari dunia ramai secara perlahan-lahan untuk dapat melepaskan diri dari ikatan keduniawian. Dengan kata Wanaprasta merupakan persiapan awal untuk mencapai moksa yang selama ini menjadi tujuan dari agama Hindu, (4) Bhiksuka atau juga disebut Sanyasin, yaitu tingkat kehidupan yang terlepas dari ikatan keduniawian. Dalam hal ini tujuan dari orang menjalani tahapan Bhiksuka adalah untuk mencapai moksa.

Berdasarkan uraian-uraian di atas, maka sudah jelas bentuk dan jenis usaha hidup yang harus dilakukan pada masing-masing pembagian catur asrama berbeda-beda. Hal ini di karenakan oleh unsur Catur Purusa Artha yang ingin dicapai pada tiap-tiap tingkatan tahapan Catur Asrama. Tiap-tiap Catur Purusa Artha wajib diwujudkan pada tahapan-tahapan Catur Asrama. Oleh karena itu Catur Asramalah yang dipakai sebagai acuan konsepsi dasar untuk mencapai empat tujuan hidup manusia yaitu Catur Purusa Artha.

Dalam hal ini pembelajaran agama Hindu yang diberikan guru sangatlah berperan dalan perubahan mental siswa itu sendiri. Dikatakan demikian karena pembelajaran agama Hindu yang diberikan kepada siswa berfungsi sebagai pengendali terhadap perbuatan siswa yang bersifat negatif dan juga pembelajaran agama Hindu pun dapat dilakukan dimana saja termasuk dirumah maupun di sekolah. Dimana dalam hal ini sekolah berperan serta dalam membentuk watak siswa yang bernafaskan Hindu. Pembelajaran agama Hindu memberikan penjelasan tentang perbuatan yang harus dilakukan dan di hindari serta mampu membedakan mana perbuatan yang baik dan mana perbuatan yang kurang baik. Begitu pula memberikan pengetahuan tentang cara melaksanakan pengorbanan/yadnya sebagai salah satu wujud Sradha dan Bhakti kepada Tuhan. Selain itu juga pembelajaran agama Hindu juga memberikan jalan untuk menghadapi tantangan dalam kehidupan ini sehingga dapat memberikan ketentraman hati serta tabah dalam menghadapi rintangan kehidupan. 
2.2.Faktor Menghambat Perubahan Mental Siswa Dalam Pembelajaran Agama Hindu

Di dalam membentuk kepribadian siswa diperlukan adanya pembelajaran agama Hindu. Dengan adanya pembelajaran agama Hindu yang diberikan kepada siswa nantinya diharapkan akan memperoleh keseimbangan antara jasmani dan rohani. Sebab apabila siswa telah dibekali dengan pembelajaran agama Hindu secara utuh maka akan dapat menghadapi tantangan jaman, yang dalam hal ini adalah kemajuan ilmu tekhnologi dan pengaruh global dengan cepat dalam kehidupan masyarakat secara modern. Dalam pelaksanaan proses pembelajaran agama Hindu masih banyak terdapat faktor yang menghambat. Hambatan tersebut terjadi karena adanya kesenjangan antara tujuan yang diinginkan dengan kenyataannya, sebab itu perubahan mental siswa masih belum maksimal. Faktor-faktor yang menjadi hambatan tersebut dirasakan oleh beberapa pihak baik dari siswa itu sendiri, guru sebagai pengajar dan juga pihak sekolah. Perubahan mental siswa dipengaruhi oleh 2 hal, yaitu faktor internal dan faktor eksternal.

\section{a. Faktor Internal}

Faktor internal adalah faktor yang berasal dari dalam diri seseorang seperti sifat, bakat, dan keturunan. Dalam hal ini sifat/ karakter siswa yang dibawa sejak lahir misalnya : sifat jahat/baik, iri, pemalu, pemarah dan pemberani. Selanjutnya bakat yakni kemampuan yang dimiliki oleh siswa itu sendiri misalnya bakat menari, melukis, acting dan bermain musik, sedangkan aspek keturunan misalnya yaitu turunan emosi, intelektualitas, dan potensi diri. Faktor internal atau faktor dalam, menentukan dan menanggapi dunia luarnya adalah bersifat selektif, hal ini berarti bahwa hal apa saja yang datang dari luar tidak begitu saja akan diterima, tetapi disini siswa tersebut biasanya mengadakan seleksi mana hal yang akan diterima dan mana hal yang tidak mau diterima. Cara-cara yang digunakan oleh siswa di dalam memberikan tanggapan terhadap objek tersebut apakah sesuatu dari luar atau objek itu dapat diterima atau tidak, hal ini dikarenakan bahwa faktor internal merupakan faktor penentu apakah sesuatu hal yang berasal dari luar dapat diterima atau tidak.

\section{b. Faktor Eksternal}

Faktor eksternal adalah faktor yang berada di luar diri seseorang yang dapat mempengaruhi mental seseorang. Sumadi Suryakarta (1980:223) menyebutkan faktor eksternal atau faktor yang datang dari luar individu siswa terdiri dari beberapa faktor yaitu:

1) Faktor Keluarga

Keluarga merupakan unsur pertama dan utama dalam kehidupan manusia, dimana ia belajar dan menyatakan diri sebagai manusia sosial di dalam berinteraksi dengan kelompoknya. Keluarga yang merupakan kelompok primer, termasuk pembentukan normanorma sosial. Di dalam keluarga dimana suatu interaksi sosial tersebut terjadi berdasarkan simpati. Hal-hal yang pertama timbul dari suatu interaksi tersebut ialah belajar untuk memperhatikan keinginan-keinginan orang lain, dan belajar bekerjasama dengan orang lain. Pengalamanpengalaman dalam interaksi sosial yang terjadi di lingkungan keluarga turut pula menentukan tingkah laku terhadap orang lain dalam pergaulan sosial di luar keluarganya dan di dalam masyarakat pada umumnya. Jadi dengan demikian peranan keluarga sebagai kerangka sosial yaitu sebagai tempat manusia berkembang sebagai makhluk sosial, 
selain itu juga terdapat peranan-peranan tertentu di dalam keadaan suatu keluarga yang dapat mempengaruhi perkembangan anak sebagai makhluk sosial seperti misalnya :

a). Status Sosial Ekonomi, dalam hal ini keadaan status ekonomi tentulah mempunyai peranan terhadap pertumbuhan mental anak. Apabila diperhatikan suatu keluarga yang memiliki perekonomian yang cukup, lingkungan material yang dihadapi anak di dalam keluarganya kuat, maka anak tersebut memiliki kesempatan yang luas untuk mengembangkan bermacam-macam kecakapannya. Dibandingkan dengan keluarga yang status ekonomi yang serba cukup, namun disini orang tuanya dapat mencurahkan perhatian yang mendalam kepada pendidikan anaknya. Tentu saja dalam hal ini status sosial ekonomi suatu keluarga bukan merupakan faktor yang mutlak dalam perkembangan sosial dan mental anak, hal itu tergantung dari pada sikap orang tuanya dan bagaimana corak interaksi di dalam keluarga tersebut.

b). Keutuhan Keluarga, yaitu suatu keluarga yang utuh juga menentukan dan mempengaruhi perkembangan dan pertumbuhan mental anak. Yang dimaksud dengan keutuhan keluarga disini adalah keutuhan dalam struktur keluarga yaitu bahwa dalam suatu keluarga itu disamping adanya ayah dan ibu serta anak. Apabila ayah dan ibu tidak ada maka suatu keluarga tersebut tidak utuh lagi, dan apabila ayah/ibu jarang di rumah atau lebih sering meninggalkan rumah karena suatu pekerjaan atau pun yang lainnya, maka struktur keluarga ini pun bisa dikatakan tidak utuh lagi. Karena suatu keluarga dapat dikatakan keluarga yang utuh bukan hanya karena kehadiran ayah dan ibu melainkan pula keutuhan interaksi yang terjadi dalam suatu keluarga. Jadi dengan demikian keutuhan keluarga sangat menentukan bagi perubahan mental anak, di dalam mereka berinteraksi baik itu dalam keluarga maupun tempat anak tersebut bergaul.

c). Sikap dan Kebiasaan Orang Tua, peranan keadaan keluarga terhadap perubahan dan perkembangan mental anak tidak hanya terletak pada status sosial ekonomi maupun keutuhan keluarganya saja melainkan disini sikap dan kebiasaan orang tua dalam mendidik anaknya memiliki peranan yang sangat penting terhadap perubahan mental anak tersebut. Orang tua sebagai pendidik secara kodrati merupakan tumpuan bagi seorang anak, dimana orang tua sebagai pendidik dan anak sebagai terdidik terdapat suatu jalinan yang akrab yaitu jalinan darah. Orang tua adalah insan yang pertama kali yang dikenal anak dan selalu berada disampingnya sehingga keduanya menjadi segala-galanya baginya yang keduanya sama-sama memangku beban secara naluriah. Keberhasilan bimbingan yang dilakukan orang tua bukanlah suatu bimbingan yang di dasari oleh rasa pamrih atau ganti rugi dari anaknya kelak, namun hal ini sama sekali tidak diharapkan dan semua itu dilakukan orang tua semata-mata karena tugas dan kewajiban orang tua sebagai guru Rupaka yang dalam ajaran agama Hindu telah diwahyukan oleh Sang Hyang Widhi Wasa. 
2) Faktor Sekolah

Di samping keluarga mempunyai peranan dalam perubahan mental siswa, sekolah juga mempunyai peranan dalam perubahan mental siswa. Pertama-tama interaksi sosial yang berlangsung di sekolah biasanya tidak mendalam dan kontinyu seperti yang terjadi di dalam keluarga hal ini dikarenakan biasanya pimpinan kelompok yang berinteraksi di sekolah yang mana siswa yang menjadi anggota kerap kali berganti-ganti dan tidak menetap seperti yang terjadi di keluarga. Namun jelas bahwa peranan sekolah terhadap perubahan mental siswa tentulah juga berperan cukup besar. Sekolah bukanlah hanya merupakan lapangan untuk mempertajam intelek saja, melainkan peranan sekolah jauh lebih luas. Di dalamnya berlangsung beberapa bentuk-bentuk dasar dari pada kelangsungan suatu pendidikan pada umumnya yaitu pembentukan sikap dan kebiasaan-kebiasaan siswa, belajar bekerjasama dengan orang lain, melaksanakan tuntutan-tuntutan, belajar menahan diri demi kepentingan orang lain, memperoleh pengajaran dan belajar menghadapi saingan dalam suatu pembelajaran. Jadi di sini sekolah memiliki peran yang cukup besar dalam perubahan mental siswa, karena disamping sekolah tempat mempertajam ilmu, di sekolah juga diajarkan pendidikan-pendidikan yang dapat membentuk mental dan tingkah laku siswa di dalam berinteraksi dengan lingkungan sekitarnya.

3) Faktor Lingkungan

Lingkungan memiliki peranan yang cukup besar terhadap perubahan mental siswa, di dalam mereka mengadakan hubungan dengan lingkungannya. Jika diperhatikan salah satu daripada lingkungan yang dapat mempengaruhi perubahan mental siswa yaitu peranan lingkungan kerja. Di dalam menguraikan lingkungan kerja dalam perubahan mental siswa terdapat kesulitan bahwa uraian tersebut kurang didasarkan atas hasil-hasil daripada penelitian-penelitian sebelumnya. Usaha mengenai pengaruh lingkungan kerja hanyalah berdasarkan observasi-observasi mengenai keadaan lingkungan kerja yang diduga dapat mempengaruhi perubahan mental siswa itu sendiri. Di antaranya ada beberapa pandangan berdasarkan observasi, yang berkisar pada lingkungan kerja yang bersifat industri modern di kota besar, dibandingkan dengan lingkungan kerja yang bercorak pertanian di kota kecil di desa. Pengaruh positif yang dapat ditimbulkan pada lingkungan kerja dalam suatu perusahaan besar yang modern yaitu, dengan adanya cara kerja yang tersusun, kebersihan dan ketelitian yang harus dipelihara di dalam perusahaan besar, maka orang yang terlibat di dalam perusahaan tersebut pun memperoleh latihan di dalamnya.

Disamping kecermatan, kecepatan, ketepatan dan keteraturan yang diperlukan dalam bermacam-macam pekerjaan dalam suatu perusahaan itu, juga mempunyai pengaruh untuk mendisiplinkan manusia dan membentuk manusia yang cakap dan terampil. Sebaliknya pengaruh negatif yang dapat ditimbulkan dari hidup dan cara kerja di suatu kota industri besar yaitu, bahwa interaksi sosial antar manusia dimana sudah tidak ada yang bersifat kekeluargaan lagi melainkan bersifat lebih individualisme atau mementingkan diri sendiri. Sedangkan pengaruh lingkungan pekerjaan yang bersifat pertanian di desa ada yang berpendapat bahwa lingkungan kerja yang seperti itu 
dapat memudahkan dalam membentuk kepribadian yang harmonis, realistis, tidak tergesa-gesa dan bersifat kekeluargaan.

\subsection{Upaya Guru Mengatasi Perubahan Mental Siswa Dalam Pembelajaran Agama Hindu}

Adapun beberapa upaya yang dilakukan untuk mengatasi hambatan-hambatan yang terjadi baik itu yang timbul dari faktor internal atau yang timbul dari dalam diri siswa tersebut atau pun faktor yang berasal dari luar diri siswa itu sendiri. Perubahan mental siswa, ruang lingkupnya mencakup 4 hal yaitu : 1) Azas, 2) Arah, 3) Sasaran dan 4) Ajaranajaran. Berdasarkan keempat ruang lingkup tersebut di atas dilaksanakan secara terpadu guna memantapkan dan meningkatkan loyalitas umat Hindu kepada Negara, bangsa dan agama yang tercermin dalam dharma agama dan dharma Negara.

Untuk mendapatkan pengertian dan pengetahuan secara utuh tentang keterlibatan guru agama Hindu dalam perubahan mental siswa, hendaknya ditempuh dengan caracara pendekatan dalam perubahan mental siswa yaitu,

1. Dalam rangka memecahkan suatu persoalan bagaimana tujuan perubahan mental siswa dapat dilaksanakan dengan melalui cara-cara pendekatan yaitu : 1) Pendekatan Sosiologis dan Sosial Psikologis yaitu berarti bahwa pematangan perubahan mental yang terjadi pada siswa terjadi melalui proses sosialisasi dengan sesama adaptasi dan komunikasi (Wiratmaja, 1977 : 77). 2) Pendekatan integratif dalam hubungan perubahan mental siswa dengan proses antar dan inte generasi (Wiratmaja, 1977 :17).

2. Memberikan contoh yang tauladan dengan menciptakan suasana kekeluargaan dengan menggunakan pedoman pelaksanaan yaitu : Menciptakan komunikasi yang baik antar siswa/siswi agar terwujudnya kondisi mental yang baik dan mantap, dan memupuk kesamaan khususnya citacita dan harapan untuk masa depannya sendiri dan umumnya untuk umat Hindu (Wiratmadja, 1977 : 17).

\section{a. Azas Perubahan Mental Siswa}

Perubahan mental siswa yang berazaskan kekeluargaan dan kerukunan, karena pada hakekatnya seluruh umat Hindu jika ditinjau dari segi agamanya kita semua adalah bersaudara, masalah status sosial yang timbul di masyarakat seperti kaya, miskin, jabatan dan kedudukan itu timbul dari karma manusia itu sendiri. Tuhan menciptakan manusia di dunia ini berdasarkan cinta kasih tanpa membeda-bedakan status, untuk itu hendaknya kita hidup di dunia ini haruslah saling asih, asah, dan asuh yang diwujudkan dengan ajaran Tri Kaya Parisudha (manacika, wacika dan kayika). Kerukunan hidup beragama dalam lingkungan sosial kemasyarakatan memerlukan sikap saling hormat menghormati dan saling menghargai pendapat orang lain. Dalam hal ini ada tiga kerukunan yang harus dibina dan di tumbuh kembangkan, yakni : a) Kerukunan intern umat beragama, b) Kerukunan antar umat beragama, dan c) Kerukunan umat beragama dengan pemerintah.

\section{b. Arah Perubahan Mental Siswa}

Pembinaan umat Hindu bertolak dari dua pendekatan, yaitu dharma Negara dan dharma agama. Melaksanakan dharma negara dengan mencintai dan berbhakti kepada tanah airnya tempat mereka berpijak dan hidup. Sedangkan melaksanakan dharma agama berarti 
menjalankan kewajiban dan taat melaksanakan ajaran-ajaran agama dan menjunjung kitab suci Weda untuk menumbuhkan dan mengembangkan mental siswa, maka sangat perlu memperhatikan kesadaran beragama tidak hanya berwujud kepekaan moral, tetapi juga kepekaan sosial yang nantinya mampu menghasilkan perubahan mental yang mantap serta kerukunan sesama pemeluk agama.

\section{c. Sasaran Perubahan Mental Siswa}

Dalam hal ini yang menjadi sasaran perubahan mental adalah para siswa. Pembelajaran agama adalah pendidikan seumur hidup yang kita dapat. Maka oleh karena itu pelaksanaan pembinaannya bukanlah di mulai dari tingkat pendidikan SMA melainkan sebaliknya pembelajaran agama Hindu tersebut telah ditanamkan sejak siswa tersebut masih kecil. Dalam hal ini sikap keteladanan yang ditunjukkan oleh orang tua adalah kunci untuk mengembangkan jiwa keagamaan pada diri siswa tersebut. Selain itu juga pengaruh lingkungan juga dapat mempengaruhi karakter siswa, perilaku siswa, dan pengembangan diri siswa. Disini siswa harus diyakini bahwa Tuhan mempunyai sifat Maha Tahu, Maha Kasih, Maha Kuasa, Maha Penyayang dan mengasihi segala ciptaanNya.

\section{SIMPULAN}

Pembelajaran agama Hindu yang diberikan kepada siswa diharapkan nantinya mampu meningkatkan dalam perubahan mental siswa, karena dengan memberikan pembelajaran agama Hindu pada siswa di harapkan selain pandai dan terampil dalam melakukan persembahyangan mereka bisa mengetahui makna dan arti agama itu sendiri. Pembelajaran agama Hindu memiliki tujuan yang sangat luas, yaitu : dapat membentuk kepribadian dan sikap mental siswa serta menumbuhkan keimanan pada diri siswa dan juga sebagai pengendali terhadap perbuatan siswa yang negatif yang nantinya dapat merugikan siswa itu sendiri. Perubahan mental pada siswa adalah suatu upaya dalam membangun suatu persepsi yang positif terhadap keyakinan maupun keimanan dari berbagai situasi yang muncul yang nantinya di hadapi siswa.

Faktor-faktor yang menghambat perubahan mental siswa dalam pembelajaran agama Hindu dipengaruhi oleh 2 faktor yaitu, faktor internal atau faktor yang berasal dari dalam diri siswa dan faktor eksternal yaitu faktor-faktor yang berasal dari luar individu siswa. (1) Disini faktor internal meliputi sifat/ karakter yang telah dibawa siswa sejak ia lahir, serta bakat yang di miliki. Faktor internal menentukan dan menanggapi dunia luarnya secara selektif ini berarti segala hal yang datang dari luar tidak begitu saja diterima melainkan disini siswa mampu menanggapi hal-hal yang bisa di terima atau yang tidak bisa di terima, (2) Faktor Eksternal yaitu faktor yang berasal dari luar diri siswa dimana disini faktor eksternal dipengaruhi oleh tiga hal yaitu : faktor keluarga, faktor sekolah dan faktor lingkungan. Ketiga hal tersebut sangat berperan dalam perubahan mental siswa, yaitu dimana dalam hal ini faktor keluarga, sekolah dan lingkungan memiliki fungsi untuk membentuk ketahanan mental dan kepribadian siswa agar nantinya mereka mampu menghadapi segala situasi dan kondisi dalam kehidupan. 


\section{DAFTAR PUSTAKA}

Suharsini, A. (1986). Manajemen Pengajaran Secara Manusiawi. Jakarta: Rineka Cipta

Budiningsih, A. (2004). Belajar dan Pembelajran. Jakarta: Gramedia.

Burhanudin. (1997). Pengantar Pedagogik (Dasar-dasar Ilmu Mendidik). Jakarta: Rhineka Cipta.

Dharmayasa, I M. (1995). Canakya Nitisastra. Denpasar : Yayasan Dharmanarada

Mulyasa, E. (2005). Kurikulum Berbasisi Kompetensi. Bandung: PT. Remaja Rosdakarya.

Pudja, I G. (1984). Panca Sradha. Denpasar: Parisada Hindu Dharma Pusat.

Purwanto, N. (2003). Psikologi Pendidikan. Bandung. PT. Remaja Rusdakarya

Slameto, (1995). Belajar dan Faktorfaktor yang mempengaruhinya. Jakarta: PT. Rineka Cipta.

Sudarsana, I. K. (2016). PEMIKIRAN TOKOH PENDIDIKAN DALAM
BUKU LIFELONG LEARNING: POLICIES, PRACTICES, AND PROGRAMS (Perspektif Peningkatan Mutu Pendidikan di Indonesia). Jurnal Penjaminan Mutu, (2016), 44-53.

Sudarsana, I. K. (2017). Interpretation Meaning of Ngaben for Krama Dadia Arya Kubontubuh Tirtha Sari Ulakan Village Karangasem District (Hindu Religious Education Perspective). Vidyottama Sanatana: International Journal of Hindu Science and Religious Studies, 1(1), 1-13.

Sudibya, I G. (1994). Hindu Menjawab Dinamika Zaman, Denpasar : Bali post.

Suja, I W. (2000). IPTEK Dan Agama Hindu Tafsir Ilmiah Ajaran Weda, Denpasar : Manikgeni.

Suryabrata, S. (2008). Psikologi Pendidikan. Jakarta: Raja Grafindo Persada.

Titib, I M. (2003). Menumbuhkembangkan Pendidikan Budi Pekerti pada Anak. Jakarta: Ganeca Exact.

Wiana, I K. (1997). Cara Belajar Agama Hindu yang Baik. Yayasan Dharma Naradha. 